\title{
Autonomia e sustentabilidade: design participativo com os produtores dos bordados do Boi da Floresta
}

\author{
Priscila Penha Coelho ${ }^{1}$, Raquel Noronha ${ }^{2}$
}

resumo:

A proposta de pesquisa trata o design como uma ferramenta capaz de gerar uma economia atemporal nos processos de produção artesanal, perpetuando o saber-fazer. Acoplando à geração de renda, os saberes culturais que permeiam o dia a dia e a imaterialidade das histórias e paixões desenvolvidas dentro da comunidade, onde se tem os pilares de uma produção que contempla a sustentabilidade. Com este fim, lançamos nosso olhar sobre o bordado produzido pelo Boi da Floresta - tradicional grupo de Bumba-meu-boi da cidade de São Luís - MA -, a fim de caminhar sob o fio de saberes tácitos que implicam a harmonia e o resultado de uma manifestação cultural de vulto expressivo. Segundo Manzini (2017), esta é uma nova forma de produzir, que aborda um outro tipo de relação entre produção e consumo - a inovação social. Não obstante é urgente, segundo Noronha (2018), pensar em novas formas de colaboração e envolvimento nas ações, a fim de considerar a ruptura das hierarquizações de conhecimentos que direcionam as discussões abordadas nos discursos e nas práticas do design. De fato, há uma certa complexidade ao se trabalhar neste contexto, no qual é necessário vivenciar minimamente a comunidade por meio de processos de design participativo e codesign. Spinuzzi (2005), ao falar em design participativo, aborda este como sendo uma forma de compreender o conhecimento a partir das formas tradicionais, tácitas e invisíveis, por intermédio daqueles que fazem parte do processo de produção. Somente a partir da compreensão do conhecimento comum, se é possível partir do universo imaterial para o espaço físico e material. Assim, esta pesquisa tem como questão norteadora, entender como o design é capaz de fomentar processos nos quais a sustentabilidade da comunidade venha partir de seus próprios princípios associativos e seus próprios produtos, levando em consideração a sazonalidade das atividades de bordado do Bumba-meu-boi. Como objetivo geral, a pesquisa busca investigar os processos criativos e associativos de um grupo de pessoas que bordam, além de promover processos de autonomia por meio do design participativo, considerando os princípios da sustentabilidade em suas dimensões culturais e econômicas. Como objetivos específicos, busca-se entender o processo criativo e de desenvolvimento de um produto na comunidade; refletir sobre os processos de autonomia e sustentabilidade em grupos produtivos urbanos, considerando o conceito de comunidades criativas; promover os processos de design participativo que acionem os princípios da sustentabilidade; e finalmente prototipar produtos que incluam participativamente os copesquisadores em sistemas de autonomia e sustentabilidade. Ao se estudar as manifestações culturais, observando seus processos de produção e suas histórias, podemos considerar os produtos locais como "produtos da sociobiodiversidade". Noronha (2011) afirma que esta expressão está relacionada à manutenção e à valorização de práticas e saberes das comunidades, além da qualidade de vida e do ambiente. Ao tomar o bordado como lócus da ação participativa, estamos tratando ainda do conceito de design de superfície, acionado por Rubim (2005) e incluído no âmbito do design têxtil, quando este for o resultado de um projeto originado a partir de um processo criativo, original e único. Espera-se que a partir desta pesquisa seja desenvolvido o mapeamento de princípios sustentáveis relacionados à comunidade em questão, tangibilizando-os por meio da prototipagem de produtos cocriados, 
possibilitando a sustentabilidade cultural e econômica para além dos períodos de atividade do Bumbameu-boi.

palavras-chave:

Sustentabilidade cultural; bordado; bumba meu boi; design participativo; geração de renda.

Referências:

1. MANZINI, Ezio. Quando todos fazem design: uma introdução ao design para a inovação social. São Leopoldo, RS. - UNISINOS, 2017.

2. NORONHA, Raquel. The collaborative turn: challenges and limits on the construction of a common plan and on autonomía in design. Strategic Design Research Journal - UNISINOS, 2018.

3. NORONHA, Raquel. Identidade é valor: as cadeias produtivas do artesanato de Alcântara. São Luís, MA. - EDUFMA, 2011.

4. RUBIM, Renata. Desenhando a superfície. São Paulo, SP. - Edições Rosari, 2004.

5. SPNUZZI, Clay. The methodology of participatory design. Technical COMMUNICATION. Volume 52, number 2. p.163-174, maio-2005. 